Saudi Journal of Business and Management Studies Abbreviated Key Title: Saudi J Bus Manag Stud ISSN 2415-6663 (Print) |ISSN 2415-6671 (Online) Scholars Middle East Publishers, Dubai, United Arab Emirates Journal homepage: https://saudijournals.com/sjbms

Original Research Article

\title{
The Effect of Compensation and Motivation on Job Satisfaction and Employee Performance at SMK Medika Samarinda
}

Piw Dorra Rosalia ${ }^{1 *}$, Sri Mintarti ${ }^{2}$, Ariesta Heksarini ${ }^{3}$

${ }^{1}$ Student, Mulawarman University, Faculty of Economics and Business, Samarinda, Indonesia

${ }^{2}$ Professor, Department of Management, Faculty of Economics and Business, Mulawarman University, Samarinda, Indonesia

${ }^{3}$ Assistant Professor, Department of Management, Faculty of Economics and Business, Mulawarman University, Samarinda, Indonesia

DOI: $10.36348 / \mathrm{sjbms.2020.v05i07.009}$

| Received: 15.07.2020 | Accepted: 24.07.2020 | Published: 28.07.2020

*Corresponding author: Piw Dorra Rosalia

\section{Abstract}

The purpose of this study is to determine the effect of compensation, motivation, job satisfaction, variables on employee performance, and the effect of job satisfaction variables on the performance of employees of SMK Medika Samarinda. The design of this research is explanatory research. This type of research is descriptive research. The method used to collect data in this study is a survey method. The population of this study was 52 employees. In the sample taken by the author using the census method, because the number of subjects is narrow and the author uses a total of 52 employees as a sample. This study uses the Structural Equation Modeling-Partial Least Square (SEM-PLS) approach to analyze data. The results of research on factors that affect job satisfaction and employee performance are as follows: 1) compensation has a significant negative effect on job satisfaction, 2) motivation has a significant positive effect on job satisfaction, 3 ) compensation has no significant positive effect on employee performance, 4) motivation Not significant positive effect on employee performance, 5) job satisfaction has a significant positive effect on employee performance. As for the indirect effect, the compensation results did not have a significant negative effect on employee performance through job satisfaction as an intervening variable, and motivation had a significant positive effect on employee performance through job satisfaction as an intervening variable. SMK Medika Samarinda in terms of increasing job satisfaction and employee performance needs to pay attention to the variables examined in work activities at school, based on research only job satisfaction has a significant effect on employee performance. This shows that job satisfaction of employees of SMK Medika Samarinda can affect employees at work.

Keywords: Compensation, Motivation, Job Satisfaction, Employee Performance.

Copyright @ 2020: This is an open-access article distributed under the terms of the Creative Commons Attribution license which permits unrestricted use, distribution, and reproduction in any medium for non-commercial use (NonCommercial, or CC-BY-NC) provided the original author and source are credited.

\section{INTRODUCTION}

Samarinda Medical Vocational School is a vocational school that has been running for 13 years. Teachers and employees who are competent in their fields are on of the things that must be possessed in order to continue to develop and compete in other schools. The management of SMK Medika must pay attention to employee performance. Management is required to be able to manage and build the performance of all employees so that they can make maximum contributions to the agencies. In addition, good relations between management and employees need to be built so that employees feel comfort and satisfaction at work. Job satisfaction is what will make employees loyal to the agency.

Seeing the importance of employees in organizations, motivation also plays an important role [1]. Low motivation makes it difficult for employees to complete the task responsibilities received because they lack enthusiasm and give up easily, and likewise if they provide the right motivation, employees will be more enthusiastic in working [2,3]. States motivation as a willingness to carry out high efforts to achieve organizational goals that are conditioned by meeting individual needs. In addition to motivation, another factor that can improve employee performance 
productivity is the provision of compensation. Providing compensation is one step by management to appreciate all kinds of employee work that has been completed. Compensation can be either material or non-material.

\section{LITERATUR REVIEW \\ Effect of Compensation on Job Satisfaction}

Compensation can help strengthen the organization's key values and facilitate organizational achievement. Employees who are compensated will be satisfied with their work and will do their jobs better [4]. Although important, compensation is a tool not a goal. Then compensation is placed on the independent variable [4].

Saman A find that compensation has a significant effect on job satisfaction. But it is different from the results of the study which found that compensation had no significant effect on job satisfaction [5-10].

Hypothesis I: Compensation has a significant positive effect on job satisfaction

\section{Effect of Motivation on Job Satisfaction}

Motivation aims to change the motivation in employees to be higher $[4,11]$ says motivation can increase energy which will have an impact on improving performance. So job satisfaction in achieving organizational goals will be affected, and lead to higher job satisfaction [4, 10, 12] found that motivation had a significant effect on job satisfaction.

\section{Hypothesis II: Motivation has a significant positive effect on job satisfaction}

\section{Effect of Compensation on Employee Performance}

Compassation is able to have an impact on sustainability of organizational activities and future planning plans [13]. Because employees will feel able to maintain their dignity, fulfill life needs by providing knowledge, skills and time to the agency [13]. Employees feel that what they are doing is valued by the agency and will continue to provide the best.

Edison E, Yohny A, \& Imas K et al. [14, 5, 6, 15] find that compensation has a significant effect on employee performance.

\section{Hypothesis III: Compensation has a positive and} significant effect on employee performance

\section{Effect of Motivation on Employee Performance}

Motivation is a situation that gives rise to the desire of the individual (self) in trying to achieve his desires [16]. Performance is the result of work completed which is the responsibility and duty of an employee and has quality [17]. Motivation can lead to individual enthusiasm to improve their expertise, even strengthen commitment to the agency, so that in the end it can improve individual performance and organizational performance [4]. Employees who have motivation are more productive than employees who have no motivation [18].

Saeed MM, \& Asghar MA. [19-21, 1, 22, 18, 23-26] find that motivation has a significant effect on employee performance. But different from the results of research [27-30, 12] which found that motivation had no significant effect on employee performance.

\section{Hypothesis IV: Motivation has a significant positive effect on employee performance}

\section{Job Satisfaction Influences Employee Performance}

Job satisfaction for employees tends to increase productivity, pride and high commitment to their work [4]. When employees feel satisfied at work, the organization will be more effective [3]. Performance by employees will also be better.

Purnama Y, Saban D, Kusumah MSA [6, 9, $12,25,26]$ find that job satisfaction has an effect significant positive on employee performance.

Hypothersis V: Job satisfaction has a positive and significant effect on employee performance

\section{METHODOLOGY}

\section{Sources and Type of Data}

Based on the type of research, this research is an expansive study, namely research to find out and explain the influence between compensation, motivation, job satisfaction, and employee performance and continued with hypothesis testing, this research is a study that explains the causal relationship between variables. This research is also included in the descriptive study, because it provides a descriptive explanation of the variables to be studied.

The population of this study was all employees of SMK Medika Samarinda totaling 52 people consisting of $22 \mathrm{emn}$ and 30 women. In taking the sample the author uses the census method, it is because in terms of the area of this study only covers a narrow area or subject [31]. Analysis of the data used by the author is Structural Equation Model-Partial Least Square (SEM-PLS).

\section{Conceptual Frameworks}

The theoretical framework in this study can be described as follows: 


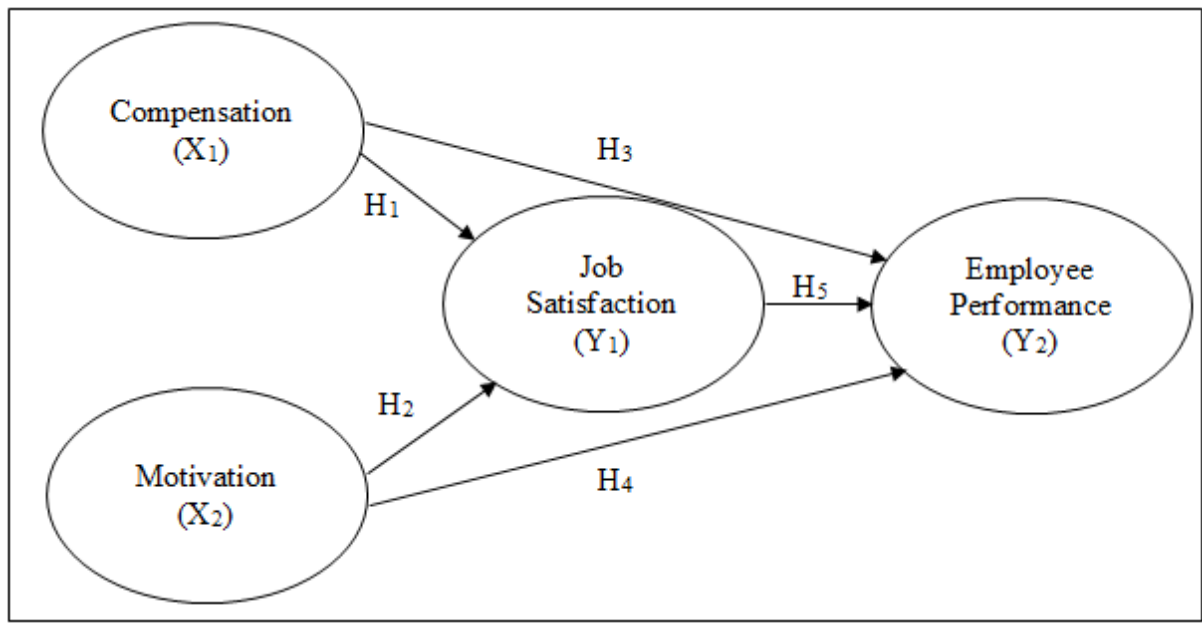

Fig-2: Conceptual Framworks

\section{Measurement of Variables}

The method of collecting data through a questionnaire method, namely by asking a number of questions to respondents adjusted to the purpose on the study. The following are indicator questions for each research variable:

Table-1: Research Variables Indicators

\begin{tabular}{|l|ll|}
\hline Variables & \multicolumn{3}{|c|}{ Calculation method } \\
\hline Compensation & 1) & Wages or salaries; \\
& 2) & Professional allowances; \\
3) & Temporary benefits; \\
& 4) & Incentives; \\
& 5) & Health; \\
& 6) & Pension funds; and \\
& 7) & Vacation. \\
\hline Motivation & 1) & Physiological needs; \\
& 2) & Security needs; \\
& 3) & Award needs; and \\
& 4) & Self-actualization needs. \\
\hline Job Satisfaction & 1) & Rewards; \\
& 2) & The work itself; \\
& 3) & Promotional opportunities; \\
& 4) & Supervision; \\
& 5) & Co-workers; \\
& 6) & Conditions of work; and \\
& 7) & Job security. \\
\hline Employee Performance & 1) & Quality; \\
& 2) & Quantity; \\
& 3) & Timeliness; \\
& 4) & Cost effectiveness; and \\
& 5) & Independence. \\
\hline
\end{tabular}

Source: data processed (2020).

\section{RESULT AND DISCUSSION}

Validity Test

Validity test used is valid or whether a questionnaire is valid. Said to be valid if the questions in the questionnaire are able to describe variables. A variable is said to be valid if the value of $r$ results is greater than $r$ table. And vice versa if the value of $r$ is smaller than $r$ table then the variable is invalid [35].

The following are the result of the validity test of the trial instrument using PLS with 52 samples: 
Table-2: Validity Test

\begin{tabular}{|c|c|c|c|}
\hline Variable & R Square & Adjusted R Square & Results \\
\hline \multirow{7}{*}{ Compensation $\left(\mathrm{X}_{1}\right)$} & $\mathrm{X} 1.1$ & 0,658 & Valid $(>0.227)$ \\
\hline & $\mathrm{X} 1.2$ & 0,895 & Valid $(>0.227)$ \\
\hline & $\mathrm{X} 1.3$ & 0,699 & Valid $(>0.227)$ \\
\hline & $\mathrm{X} 1.4$ & 0,724 & Valid $(>0.227)$ \\
\hline & $\mathrm{X} 1.5$ & 0,897 & Valid $(>0.227)$ \\
\hline & $\mathrm{X} 1.6$ & 0,813 & Valid $(>0.227)$ \\
\hline & $\mathrm{X} 1.7$ & 0,782 & Valid $(>0.227)$ \\
\hline \multirow{4}{*}{ Motivation $\left(\mathrm{X}_{2}\right)$} & $\mathrm{X} 2.1$ & 0,747 & Valid $(>0.227)$ \\
\hline & $\mathrm{X} 2.2$ & 0,853 & Valid $(>0.227)$ \\
\hline & $\mathrm{X} 2.3$ & 0,851 & Valid $(>0.227)$ \\
\hline & $\mathrm{X} 2.4$ & 0,826 & Valid $(>0.227)$ \\
\hline \multirow{7}{*}{ Job Satisfaction $\left(\mathrm{Y}_{1}\right)$} & Y1.1 & 0,751 & Valid $(>0.227)$ \\
\hline & Y1.2 & 0,832 & Valid $(>0.227)$ \\
\hline & Y1.3 & 0,836 & Valid $(>0.227)$ \\
\hline & Y1.4 & 0,893 & Valid $(>0.227)$ \\
\hline & Y1.5 & 0,860 & Valid $(>0.227)$ \\
\hline & Y1.6 & 0,835 & Valid $(>0.227)$ \\
\hline & Y1.7 & 0,921 & Valid $(>0.227)$ \\
\hline \multirow{5}{*}{ Employee Performance $\left(\mathrm{Y}_{2}\right)$} & Y2.1 & 0,935 & Valid $(>0.227)$ \\
\hline & Y2.2 & 0,943 & Valid $(>0.227)$ \\
\hline & Y2.3 & 0,912 & Valid $(>0.227)$ \\
\hline & Y2.4 & 0,898 & Valid $(>0.227)$ \\
\hline & Y2.5 & 0,881 & Valid $(>0.227)$ \\
\hline
\end{tabular}

Source: output SmartPLS (2020).

\section{Reliability Test}

Reliability is an index that illustrates the extent to which the gauges are reliable. The technique used to conduct reliability testing is to use alpha cronbach. If reliability of less than 0.60 is considered bad, reliability in the range of 0.70 is acceptable, and more than 0.80 is good [35].
Based on the research results of the questionnaire distributed to 52 respondents, it can be seen that the results of the PLS data processing shows that the $r$ results of all variables stated are greater than $r$ tables. Tus it can be concluded that the questionnaire on each indicator is said to be valid and can then be used in research.

Table-3: Reliability Test

\begin{tabular}{|l|l|c|}
\hline \multicolumn{1}{|c|}{ Variable } & Cronbach's Alpha & Results \\
\hline Compensation $\left(\mathrm{X}_{1}\right)$ & 0,894 & Reliable $(>0.6)$ \\
\hline Motivation $\left(\mathrm{X}_{2}\right)$ & 0,837 & Reliable $(>0.6)$ \\
\hline Job satisfaction $\left(\mathrm{Y}_{1}\right)$ & 0,934 & Reliable $(>0.6)$ \\
\hline Employee Performance $\left(\mathrm{Y}_{2}\right)$ & 0,951 & Reliable $(>0.6)$ \\
\hline
\end{tabular}

Source: output SmartPLS (2020).

Based on the resuls of the reliability test, it is known that the Cronbach alphabet number is greater than the minimum value (0.60). Therefore, it can be concluded that the research instrument used to measure the compensation, motivation, job satisfaction, and employee performance variables can be said to be reliable and can then be used in research.

\section{Hypothesis Results}

To observe the factors that influence job satisfaction and employee performance, this study will use factors that can directly and indirectly affect the performance of employees at SMK Medika Samarinda. The variables taken to represent these factors are compensation, motivation, and job satisfaction.
Variables are defined first and then how they can directly or indirectly affect employee performance.

The size of the significant of the hypothesis of residence can be used in comparison t-table and $\mathrm{t}$ statistics. If the $\mathrm{t}$-statistic value is higher thatn the $\mathrm{t}$ table value, it means that the hypothesis is supported. For $95 \%$ condifence (alpha 5\%), the t-table value for the one-tailed hypothesis is $>1.96$. thus if the t-statistic value $>1.96$, the research hypothesis is proven.

The smart PLS program is carried out by t-test on each track. The test results can be seen in table 4 and table 5 below: 
Piw Dorra Rosalia et al; Saudi J Bus Manag Stud, July., 2020; 5(7): 448-454

Table-4: Bootstrapping Test

\begin{tabular}{|l|l|l|l|l|l|l|}
\hline \multicolumn{1}{|c|}{ Variable } & $\begin{array}{l}\text { Original } \\
\text { Samples }\end{array}$ & $\begin{array}{c}\text { Sample } \\
\text { Mean }\end{array}$ & $\begin{array}{c}\text { Standard } \\
\text { Deviation }\end{array}$ & T-Statistic & $\begin{array}{c}\text { P- } \\
\text { Values }\end{array}$ & Conclusion \\
\hline $\begin{array}{l}\text { Compensation (X1) } \rightarrow \text { Job } \\
\text { Satisfaction (Y1) }\end{array}$ & $-0,140$ & $-0,119$ & 0,090 & 1,551 & 0,122 & Rejected \\
\hline $\begin{array}{l}\text { Motivation (X2) } \rightarrow \text { Job } \\
\text { Satisfaction (Y1) }\end{array}$ & 0,972 & 0,956 & 0,077 & 12,620 & 0,000 & Received \\
\hline $\begin{array}{l}\text { Compensation (X1) } \rightarrow \text { Employee } \\
\text { Performance (Y2) }\end{array}$ & 0,139 & 0,165 & 0,163 & 0,852 & 0,394 & Rejected \\
\hline $\begin{array}{l}\text { Motivation (X2) } \rightarrow \text { Employee } \\
\text { Performance (Y2) }\end{array}$ & 0,190 & 0,164 & 0,207 & 0,918 & 0,359 & Rejected \\
\hline $\begin{array}{l}\text { Job Satisfaction (Y1) } \rightarrow \\
\text { Employee Performance (Y2) }\end{array}$ & 0,549 & 0,554 & 0,167 & 3,290 & 0,001 & Received \\
\hline $\begin{array}{l}\text { Compensation (X1) } \rightarrow \text { Job } \\
\text { Satisfaction (Y1) }\end{array}$ & $-0,140$ & $-0,119$ & 0,090 & 1,551 & 0,122 & Rejected \\
\hline
\end{tabular}

Source: output SmartPLS (2020).

Table-4: Indirect Effect Test

\begin{tabular}{|l|l|l|l|l|l|l|}
\hline \multicolumn{1}{|c|}{ Variable } & $\begin{array}{c}\text { Original } \\
\text { Samples }\end{array}$ & $\begin{array}{c}\text { Sample } \\
\text { Mean }\end{array}$ & $\begin{array}{c}\text { Standard } \\
\text { Deviation }\end{array}$ & T-Statistic & $\begin{array}{c}\boldsymbol{P} \text { - } \\
\text { Values }\end{array}$ & Conclusion \\
\hline $\begin{array}{l}\text { Compensation (X1) } \rightarrow \text { Job } \\
\text { Satisfaction (Y1) } \rightarrow \text { Employee } \\
\text { Performance (Y2) }\end{array}$ & $-0,077$ & $-0,070$ & 0,057 & 1,351 & 0,177 & Rejected \\
\hline $\begin{array}{l}\text { Motivation (X2) } \rightarrow \text { Job } \\
\text { Satisfaction (Y1) } \rightarrow \text { Employee } \\
\text { Performance (Y2) }\end{array}$ & 0,534 & 0,533 & 0,175 & 3,049 & 0,002 & Received \\
\hline
\end{tabular}

Source: output SmartPLS (2020).

Based on the analysis results in tables 4 and 5 above, the results of the research can be discussed as follows:

1) Compensation gives a negative influence on job satisfaction with a value of -0.140 , it can be seen that compensation gives no significant effect on job satisfaction because of t-statistics $(1.551<1.96)$, so the results of the study are not in line with the hypothesis which states compensation directly significant effect on job satisfaction.

2) Motivation gives a positive influence on job satisfaction with a value of 0.972 , it can be seen that motivation provides a significant effect on job satisfaction due to t-statistics (12.620>1.96), so the results of the study are in line with the hypothesis which states that motivation directly has a significant effect on job satisfaction.

3) Compensation has a positive influence on employee performance with a value of 0.139 , it can be seen that compensation has a significant effect on employee performance due to t-statistics $(0.852$ $<1.96$ ), so the results of the study are not in line with the hypothesis that compensation directly has a significant effect on employee performance.

4) Motivation gives a positive influence on employee performance with a value of 0.190 , it can be seen that motivation gives insignificant influence on employee performance because of $t$-statistics $(0.918<1.96)$, so the results of the study are not in line with the hypothesis that motivation directly influences significant on employee performance.
5) Job satisfaction gives a positive influence on employee performance with a value of 0.549 , it can be seen that job satisfaction gives a significant effect on employee performance due to the results of hypothesis testing (3.290>1.96), so the results of the study are in line with the hypothesis which states job satisfaction directly significant effect on employee performance.

6) Compensation gives a negative influence on employee performance through job satisfaction with a value of -0.077 , it can be seen that compensation provides no significant effect on employee performance through job satisfaction due to t-statistics $(1,351<1.96)$, so the results of the hypothesis state compensation in indirect does not significantly influence employee performance through job satisfaction.

7) Motivation provides a positive influence on employee performance through job satisfaction with a value of 0.534 , it can be seen that motivation gives a significant effect on employee performance through job satisfaction due to t-statistics (3.049> 1.96), so the hypothesis results imply motivation indirectly significant effect on employee performance through job satisfaction.

\section{CONCLUSION}

In an effort to increase job satisfaction and employee performance, agencies need to pay attention to factors that can influence. The variables studied were found to be able to influence job satisfaction is 
motivation. Motivation given to employees in agencies needs to be maintained. Although the motivation given has not been able to influence employee performance. Management allows to increase motivation that has not been maximized, providing opportunities for permanent staff appointments so that employees of SMK Medika Samarinda provide the best performance and are more enthusiastic.

While the compensation variable given does not affect job satisfaction and employee performance. Management needs to provide more compensation to its employees. Such as providing opportunities for competent and high-quality employees and teachers to become permanent employees, so that the compensation received will be in accordance with their performance. Compensation that can be given such as providing health benefits or mutual entertainment, this is in addition to increasing job satisfaction, the employee's performance will be better. Because employees feel their work is appreciated. The satisfaction that is gained will create loyalty at SMK Medika Samarinda.

\section{REFERENCES}

1. Suwuh, M. (2015). The Influence of Leadership Style, Motivation, and Work Discipline on Employee Performance at Bank Sulut KCP Likupang. Jurnal Riset Ekonomi, Manajemen, Bisnis Dan Akuntansi, 3(4), 611-619

2. Harwiki, W. (2016). The Impact of Servant Leadership on Organization Culture, Organizational Commitment, Organizational Citizenship Behaviour (OCB) and Employee Performance in Women Cooperatives. ProcediaSocial and Behavioral Sciences, 219, 283-290.

3. Robbins, S.P., \& Judge, T.A. (2009). Perilaku Organisasi (Organizational Behavior). (12 ed). Jakarta: Salemba Empat.

4. Edison, E., Yohny, A., \& Imas K. (2016). Manajemen Sumber Daya Manusia. Bandung: Alfabeta.

5. Saman, A. (2020). Effect of Compensation on Employee Satisfaction and Employee Performance. International Journal of Economics, Business and Accounting Research (IJEBAR), 4(1), 185-190

6. Purnama, Y., \& Iqbal, M. A. (2020). Effect of Compensation, Career Development on the Performance of Employees Through Job Satisfaction as Intervening Variable (Case Study at PT. Bank Syariah Mandiri in Indonesia).

7. Adil, H., Rao, C. V. K., Ayaz, M. Q., \& Shinwari, A. (2020). Effect of Compensation Packages on Job Satisfaction and Employees' Retention: A Case of Jalalabad-Based Private Universities of Afghanistan. Asia Pasific Journal of Multidisciplinary Resarch, 8(2), 26-35

8. Kamath, V., \& Verma, N. (2020). Study on Impact of Compensation on Faculties' Job Satisfaction in Educational Institutions. International Journal of
Computer Science and Information Security (IJCSIS), 18(4), 1-13.

9. Saban, D., Basalamah, S., Gani, A., \& Rahman, Z. (2020). Impact of Islamic Work Ethics, Competencies, Compensation, Work Culture on Job Satisfaction and Employee Performance: The Case of Four Star Hotels. European Journal of Business and Management Research, 5(1), 1-8

10. Kusumah, M. S. A. (2015). Pengaruh Kompensasi dan Motivasi Terhadap Kepuasan Kerja Karyawan Pada PT. Ampel Jaya di Surabaya. Jurnal Bisnis Indonesia, 6(2), 149-162

11. Sherman, A.W. Jr., Bohlader, G.W., \& Chruden, H.J. (1998). Managing Human Resource. (8 ed). Ohio: South-Western Publishing.

12. Pananrangi, M., Lewangka, O., \& Sudirman, I. (2020). The Influence of Motivation and Job Satisfaction on Employee Performance in PT. Son Karella Mare. Hasanuddin Journal of Applied Business and Entrepeneurship, 3(2), 20-32

13. Suwanto, \& Priansa, D.J. (2014). Manajemen SDM Dalam Organisasi Publik dan Bisnis. Bandung: Alfabeta.

14. Risambessy, A., Swasto, B., Thoyib, A., \& Astuti, E. S. (2012). The Influence of Transformational Leadership Style, Motivation, Burnout towards Job Satisfaction and Employee Performance. Journal of Basic and Applied Scientific Research, 2(9):88338842

15. Hartati, T. (2020). Analysis of Influence of Motivation, Competence, Compensation toward Performance of Employee. Budapest International Research and Critcs Institute-Journal, 3(2), 10311038

16. Sunyoto, D. (2013). Teori, Kuesioner, dan Proses Analisis Data Perilaku Organisasional. (T. Admojo, Ed.) (1 ${ }^{\text {st }}$ od.). Yogyakarta: Center of Academi Publishing Service (CAPS).

17. Mangkunegara, A. P. (2010). Perilaku Dan Budaya Organisasi. Bandung: Refika Aditama.

18. Jayaweera, T. (2015). Impact of Work Environmental Factors on Job Performance, Mediating Role of Work Motivation: A Study of Hotel Sector in England. International Journal of Business and Management, 10(3), 271-278.

19. Saeed, M. M., \& Asghar, M. A. (2012). Examining the Relationship between Training, Motivation and Employees Job Performance-The Moderating Role of Person Job Fit. Journal of Basic and Applied Scientific Research, 2(12), 12177-12183. Retrieved from

20. Arifin, A., hamid, D., \& Hakam, M. S. (2014). Pengaruh Pemberdayaan dan Motivasi Terhadap Kinerja Karyawan (Studi pada Karyawan CV. Catur Perkasa Manunggal). Jurnal Administrasi Bisnis, 8(2), 1-8.

21. Ganta, V. C. (2014). Motivation in the Workplace To Improve the Employee Performance. International Journal of Engineereing Technology Management and Applied Sciences, 2(6), 221-23. 
22. Elqadri, Z. M., Priyono, P., Suci, R. P., \& Chandra, T. (2015). Effect of Leadership Style, Motivation, and Giving Incentives on the Performance of Employees-PT. Kurnia Wijaya Various Industries. International Education Studies, 8(10), 183-192.

23. Sardjana, E. K., Suharto, D. G., \& Sudarmono. (2018). Effect of Remuneration, Work Discipline, Motivation on Performance. International Journal of Multicultural and Multireligious Understanding, 5(6), 136-150.

24. Natsir, M., Riduwan, A., \& Ujianto. (2018). Employee Satisfaction and Performance: The Impact Analysis On Leadership, Work Motivation, Work Discipline And Compensation. IOSR Journal of Business and Management, 20(4), 6-12.

25. Ulfa, M., Hamid, N., \& Rasyid, W. (2020). The Influence of Organizational Culture, Leadership, and Motivation through Job Satisfaction on Employee Performance at Hasanuddin University Hospital. Hasanuddin Journal of Business Strategy, 2(1), 1-14

26. Lubis, R. K. (2020). Analysis of Effect of Work Motivation and Job Satisfaction Performance against Serdang Agricultural Extension Bedagai. Journal of Management Science (JMAS), 3(1), 1924

27. Susanty, A., \& Baskoro, S. W. (2012). Pengaruh Motivasi Kerja Dan Gaya Kepemimpinan Terhadap Disiplin Kerja Serta Dampaknya Pada Kinerja Karyawan (Studi Kasus Pada PT. PLN (Persero) APD Semarang). J@Ti Undip, 7(2), 77-84.
28. Rini, \& Hazizma, L. S. (2013). Pengaruh Pemberdayaan Karyawan, Kemahiran Diri dan Keterlibatan Karyawan Terhadap Kepuasan Kerja dan Kinerja Pegawai (Studi pada Karyawan Politeknik Negeri Sriwijaya). Jurnal Manajemen Dan Bisnis Sriwijaya, 11(3), 233-244.

29. Purwanta, F. F., \& Nawangsari, L. C. (2018). The Influence of Work Motivation, Organizational Culture, and Work Environment on the Work Discipline of Employees PT Inti Karya Persada Tehnik. International Journal of Scientific and Research Publications, 8(12), 86-92.

30. Rahmi, A., Achmad, G. N., \& Adhimursandi, D. (2020). The Effect of Leadership and Empowerment Style and Motivation on Work Discipline and Employee Performance in Sungai Kunjang Subdistrict, Samarinda City. International Journal of Business and Management Invention (IJBMI), 9(3), 8-14

31. Arikunto, S. (2010). Prosedur Peneitian Status Pendekatan Praktik. Jakarta: PT. Rineka Cipta.

32. Sutrisno, E. (2015). Manajemen Sumber Daya Manusia. Jakarta: Kencana Prenadamedia Group.

33. Ivancevich, John M., Robert K., \& Michael T.M. (2006). Perilaku dan Manajemen Organisasi. (7 ed). Jakarta: Erlangga.

34. Robbins, S.P. (2006). Perilaku Organisasi. (10 ed). Jakarta: PT. Indeks Kelompok Gramedia.

35. Ghozali, I., \& Latan, H. (2014). Partial Least Squares Konsep, Metode dan Aplikasi Menggunakan Program Wrap PLS 4.0. Semarang: Undip. 